\title{
Comparison of the nutrient composition of royal jelly and worker jelly of honey bees (Apis mellifera)
}

\author{
Ying WAng, Lanting MA, Weixing Zhang, Xuepei CuI, Hongfang WAng, Baohua XU \\ College of Animal Science and Technology, Shandong Agricultural University, Tai' an, Shandong 271018, People's \\ Republic of China
}

Received 9 December 2014 - Revised 14 March 2015 - Accepted 2 June 2015

\begin{abstract}
In this study, the chemical and mineral composition and trace elements in royal jelly (RJ) and worker jelly (WJ) and in royal jelly on particular days (only-2-day RJ [O2d], only-3-day RJ [O3d] and only-4-day RJ [O4d]) were determined. Significant differences in levels of moisture, protein, 10-hydroxy-2-decenoic acid (10-HDA), fructose $(\mathrm{F})$ and glucose $(\mathrm{G})$ were found between the RJ and WJ samples. The nutrient content was significantly higher in samples on $\mathrm{O} 2 \mathrm{~d}$ than the O3d and O4d samples. The results of this study add to the current knowledge of the nutritional value of RJ and WJ. These results also imply a strong relationship between nutritional effects and polyphenism in honey bees.
\end{abstract}

chemical / composition / royal jelly / worker jelly

\section{INTRODUCTION}

The characteristics of organisms are considered to be the comprehensive result of both genetics and the environment. The honey bee is a perfect model to explore the interaction of these two factors. Genetic factors are decisive in sex determination in honey bees. The females (workers or queens) are developed from fertilized eggs, and unfertilized eggs become drones (males). Although the queen and worker have the same genotype, they differ greatly in their behavior, physiology and development (Winston 1991), and this is most likely the result of environment factors. Both the queen and worker larvae are fed royal jelly for the first 3 days of that stage. The worker larvae are subsequently fed a mixture of royal jelly, pollen and honey, while the older queen larvae are provided with abundant royal jelly (Haydak 1943). The quality and quantity of larval

Corresponding author: B. Xu, bhxu@sdau.edu.cn Manuscript editor: Stan Schneider food is believed to be the primary catalyst for the differentiation in development (Haydak 1943; Winston 1991). There are few reports on the differences between royal jelly (RJ) and worker jelly (WJ). Studies have shown that the moisture content of RJ is lower than that of WJ (Elser 1928; Smith 1959). Sugar is another important factor that may influence caste determination. Asencot and Lensky (1988) found that the food of 1 - to 3-day-old queen larvae contained $12.4 \%$ sugars, which was approximately four times that found in WJ. Studies have also found that adding sugars to WJ induced larvae to become queens (Asencot and Lensky 1985). Recent reports have noted that caste determination in honey bees is influenced by a $57-\mathrm{kDa}$ protein in royal jelly through an epidermal growth factor receptor (EGFR)-mediated signaling pathway (Kamakura 2011). While these studies strongly suggest a close relationship between food nutrients and caste determination, we still have little knowledge regarding the differences in chemical composition between RJ and WJ, such as the content of proteins, lipids, 10-hydroxy-2-decenoic acid (HDA) and mineral elements. 
The composition of RJ has been the subject of investigation by numerous researchers for more than a century (Lercker et al. 1981; cf. reviews: Ramadan and Al-Ghamdi 2012). The content of moisture (Sabatini et al. 2009), carbohydrates (Asencot and Lensky 1988; Lercker et al. 1992), proteins (Simúth 2001; Boselli et al. 2003; GarciaAmoedo and Almeida-Muradian 2007), lipids (Lercker et al. 1992; Noda et al. 2005), 10-HDA (Bloodworth et al. 1994; Koshio and de AlmeidaMuradian 2003; Pamplona et al. 2004) and minerals (Benfenati et al. 1986; Stocker et al. 2005; Garcia-Amoedo and Almeida-Muradian 2007) has been thoroughly documented. However, it is important to note that almost all of these studies were focused on the quality of commercial RJ (i.e., the food of 4-day-old queen larvae). Furthermore, the food of queen larva in its cell is increasing daily, and the larva always eat the freshest food. It is doubtful that there is any change in the composition of the RJ that the queen larvae is fed daily by nurse bees. This study is based on the hypothesis that the composition of whole RJ obtained from a cell is different from that supplied to queen larva by nurse workers on a particular day.

If the nutrient composition of RJ and $\mathrm{WJ}$ are different, we will be forced to reexamine the relationship between nutrients and caste determination in honey bees. The aim of this study was the systematic investigation of the chemical composition (including moisture, total protein, 10-HDA, carbohydrates and minerals) of different-aged samples of RJ and WJ.

\section{MATERIALS AND METHODS}

\subsection{Collection of RJ and WJ samples}

All experiments and surveys were conducted in the experimental apiary of Shandong Agricultural University (Tai' an, Shandong Province, China). RJ and WJ sampling was conducted between September and October 2014. Five queen-right colonies (Apis mellifera L.) were used in our experiments. RJ and WJ production were conducted in the five colonies at the same time.

To obtain same-aged WJ and RJ samples, the queen of each colony was confined on an empty comb for $24 \mathrm{~h}$ using a queen spawning controller (Changge Jihong Beekeeping Equipment Co., He'nan, China). The laid-comb was then transferred to a super and the queen was kept in the hive body. A queen excluder was used to separate the queen from the super. After the eggs were deposited, the 1-day-old larvae were grafted into artificial cells using a standard royal jelly production technique (Chen et al. 2002). Every 24 h, 100 worker larvae of each colony were removed from the cells, and the WJ were obtained using a retractable Chinese-style grafting tool. The RJ samples of particular days were divided into two portions: the whole RJ samples and the RJ samples that the nurse bees fed the queen larvae on that particular day (see Figure 1). A mark was made on the surface of the artificial cells. To obtain each day's RJ samples, the RJ added on top of the mark from the previous day in each cell was collected (Figure 1). Each type of RJ sample was obtained from 33 queen cells in each colony. Sampling was performed on the following days: only-2-day RJ (O2d), only-3-day RJ (O3d) and only-4-day RJ $(\mathrm{O} 4 \mathrm{~d})$. We collected five individual samples for
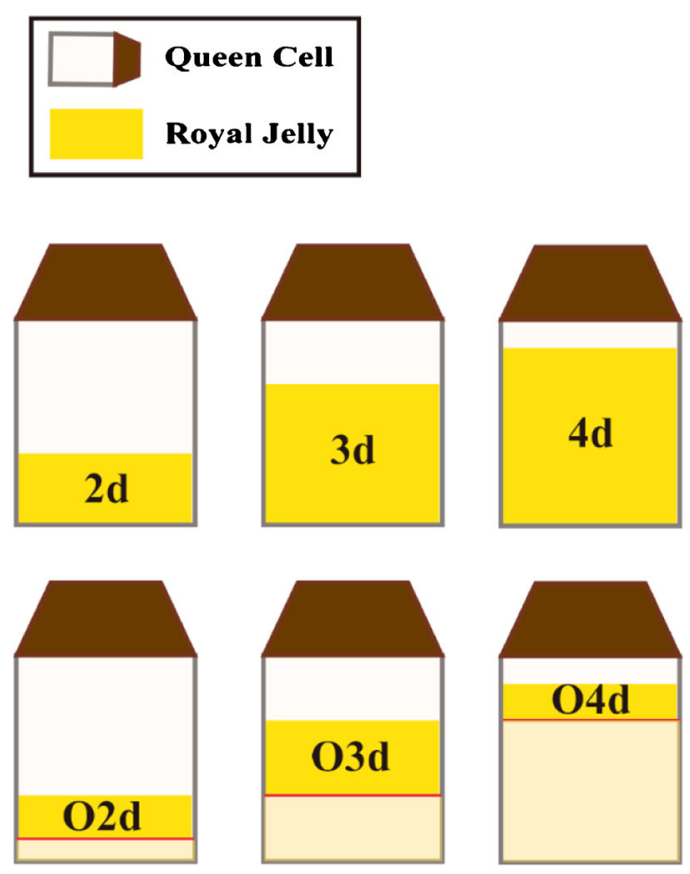

Figure 1. Schematic diagram of various RJ samples. 
each sample type (2d-, 3d-, 4d-RJ and WJ, 5d-WJ and $\mathrm{O} 2 \mathrm{~d}-, \mathrm{O} 3 \mathrm{~d}-$ and $\mathrm{O} 4 \mathrm{~d}-\mathrm{RJ}$ ) from each colony. We did not collect 1-day-old WJ or RJ samples, as there is very little 1-day $\mathrm{WJ}$, and the 1-day-old larvae are too small to separate.

\subsection{Analytical procedures}

Moisture content was determined using a vacuum freeze-drying method (Messia et al. 2005). Total crude protein was estimated using the Kjeldahl method, as reported by Hoegger (1998). The 10-HDA content was analyzed using highperformance liquid chromatography (HPLC) as defined in the national industry standard for royal jelly (GB/T 9697-2008) of the General Administation of Quality Supervision, Inspection and Quarantine of the People's Republic of China (2008). The two main sugars of RJ and WJ (fructose and glucose) were quantified using HPLC, as reported by Sesta (2006).

To determine levels of trace elements, approximately $0.5 \mathrm{~g}$ (to the nearest $0.1 \mathrm{mg}$ ) of the RJ and WJ samples was first digested using a $20-\mathrm{mL}$ mixture of $4: 1, \mathrm{HNO}_{3}: \mathrm{H}_{2} \mathrm{O}_{2}$ for $24 \mathrm{~h}$. The mixture was heated to $300{ }^{\circ} \mathrm{C}$, and when the color of the mixture turned dark, several drops of $\mathrm{H}_{2} \mathrm{O}_{2}(30 \%$, $\mathrm{v} / \mathrm{v})$ were added until it became colorless. The solution was transferred to a $25-\mathrm{mL}$ volumetric flask and filled to volume with $5 \% \mathrm{HNO}_{3}$. Blank digestions of non-RJ or non-WJ samples were conducted in the same manner in order to eliminate reagent errors. The content of eight mineral elements was determined by atomic absorption spectroscopy (AA-6601 F; Shimadzu Corporation, Kyoto, Japan) using the method described by Chen et al. (2006).

\subsection{Statistical analysis}

Before analyses were performed, Bartlett's and Levene's tests were used to ensure that the data conformed to the assumptions of ANOVA. Data were statistically analyzed using the one-way ANOVA procedure in SAS (version 9.1, SAS Institute Inc. 2003; Cary, NC, USA). Duncan's multiple-range test was used to compare differences between means, and differences were deemed significant at the $P<0.05$ level. All values are reported as mean $\pm \mathrm{SD}$.

\section{RESULTS}

The proximate composition and mineral element content of the RJ and WJ samples are shown in Tables I and II, respectively.

The moisture content of WJ was significantly higher than that of RJ for all 3 days $(2 \mathrm{~d}$ : $\mathrm{F}=321.5$, $P<0.01 ; 3 \mathrm{~d}: \mathrm{F}=66.0, P<0.01 ; \mathrm{d} 4: \mathrm{F}=300.6$, $P<0.01$ ) (Table I). For WJ, the moisture was higher on $2 \mathrm{~d}, 3 \mathrm{~d}$ and $4 \mathrm{~d}$, but decreased rapidly on $\mathrm{d} 5(\mathrm{~F}=110.1, P<0.01)$. However, unlike that of the $\mathrm{WJ}$, the moisture content of the RJ increased with time and was significantly lower on $\mathrm{d} 2$ ( $\mathrm{F}=31.1, P<0.01$ ).

The proportion of total protein in the RJ was significantly higher than that in the WJ on $\mathrm{d} 2$ and d3 (2d: F=987.9, $P<0.01 ; 3 \mathrm{~d}: \mathrm{F}=9.1, P<0.05)$; however, similar protein content was found in the $\mathrm{d} 4 \mathrm{RJ}$ and $\mathrm{WJ}$ samples $(\mathrm{F}=0.7, P>0.05)$. The $\mathrm{WJ}$ maintained a relatively stable protein content at $\mathrm{d} 2, \mathrm{~d} 3$ and $\mathrm{d} 4$, but it decreased significantly on $\mathrm{d} 5$ $(\mathrm{F}=27.4, P<0.01)$. The protein content in the $\mathrm{RJ}$ significantly decreased from $\mathrm{d} 2$ to $\mathrm{d} 4(\mathrm{~F}=73.1$, $P<0.01)$.

WJ and RJ had similar trends in decreasing proportion of 10-HDA over time; however, significant differences were found between $\mathrm{WJ}$ and RJ on d2, d3 and d4 (2d: F=63.2, $P<0.01 ; 3 \mathrm{~d}$ : $\mathrm{F}=12.0, P<0.05 ; \mathrm{d} 4: \mathrm{F}=33.8, P<0.01)$. The $10-$ HDA content of WJ was maintained at a relatively stable level of approximately 1.50 to $1.80 \%$ during the first 3 days, and was then reduced significantly at $\mathrm{d} 4$ and $\mathrm{d} 5(\mathrm{~F}=48.6, P<0.01)$. Although $\mathrm{RJ}$ had the lowest 10-HDA content on $\mathrm{d} 4$, it was still at a higher level than that of WJ.

Both the fructose and glucose levels in the RJ were significantly higher than those for the $\mathrm{WJ}$ at $\mathrm{d} 2$, d3 and $\mathrm{d} 4$ (2d: $\mathrm{F}=266.7, P<0.01 ; 3 \mathrm{~d}: \mathrm{F}=59.7$, $P<0.05 ; \mathrm{d} 4: \mathrm{F}=48.8, P<0.01$ and $2 \mathrm{~d}: \mathrm{F}=43.5$, $P<0.01 ; 3 \mathrm{~d}: \mathrm{F}=1080.5, P<0.05 ; \mathrm{d} 4: \mathrm{F}=85.8$, $P<0.01$, respectively). In the first 3 days, the content of fructose and glucose in the RJ was three times that of the WJ. The food of the worker larvae had the highest levels of fructose and glucose at $\mathrm{d} 5(\mathrm{~F}=39.3, P<0.01$ and $\mathrm{F}=21.6$, $P<0.01$, respectively). The fructose and glucose content of RJ were maintained at a relatively stable level during these 3 days, despite the significantly increased fructose level on $4 \mathrm{~d}(\mathrm{~F}=8.9$, 


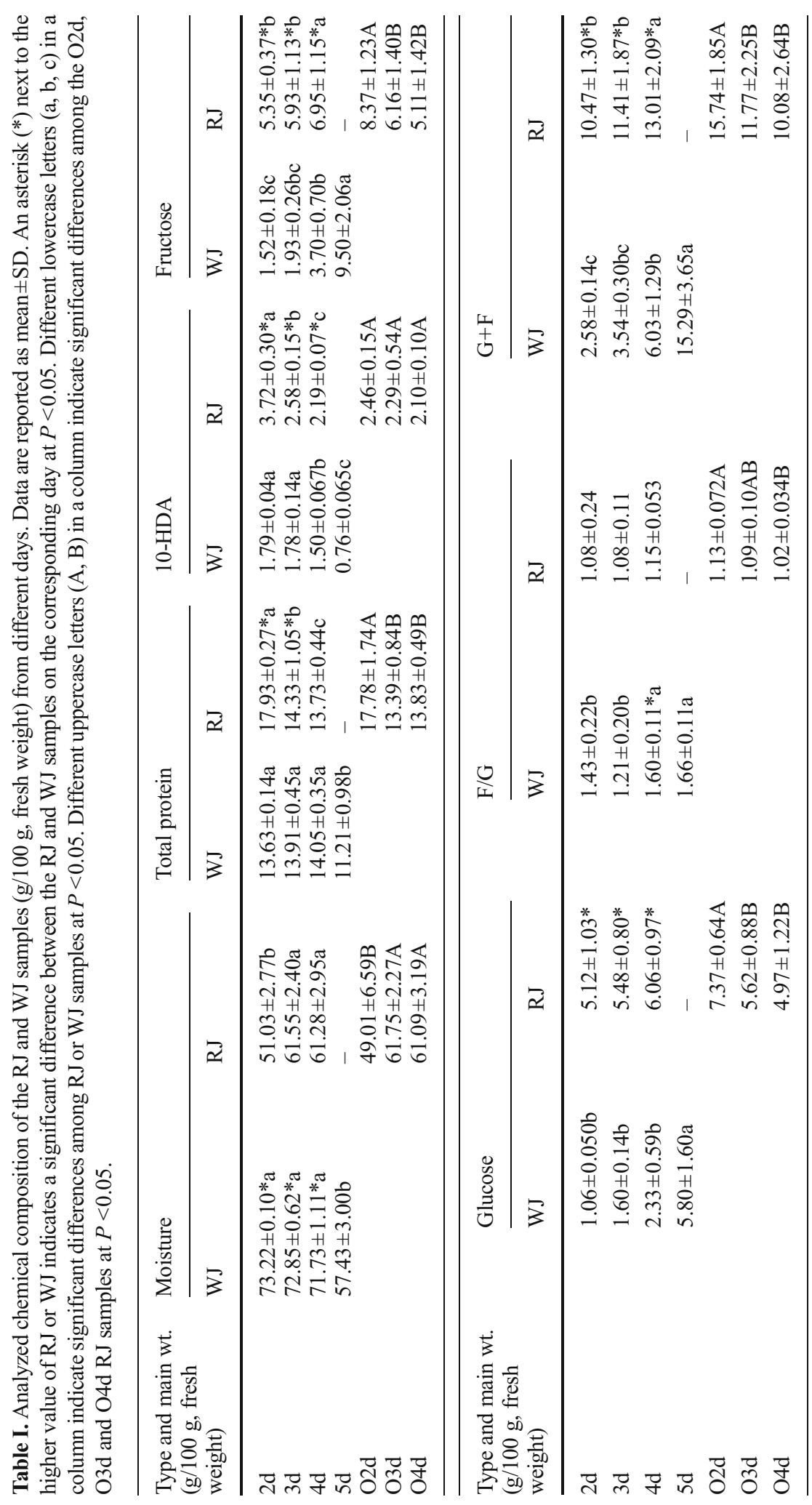




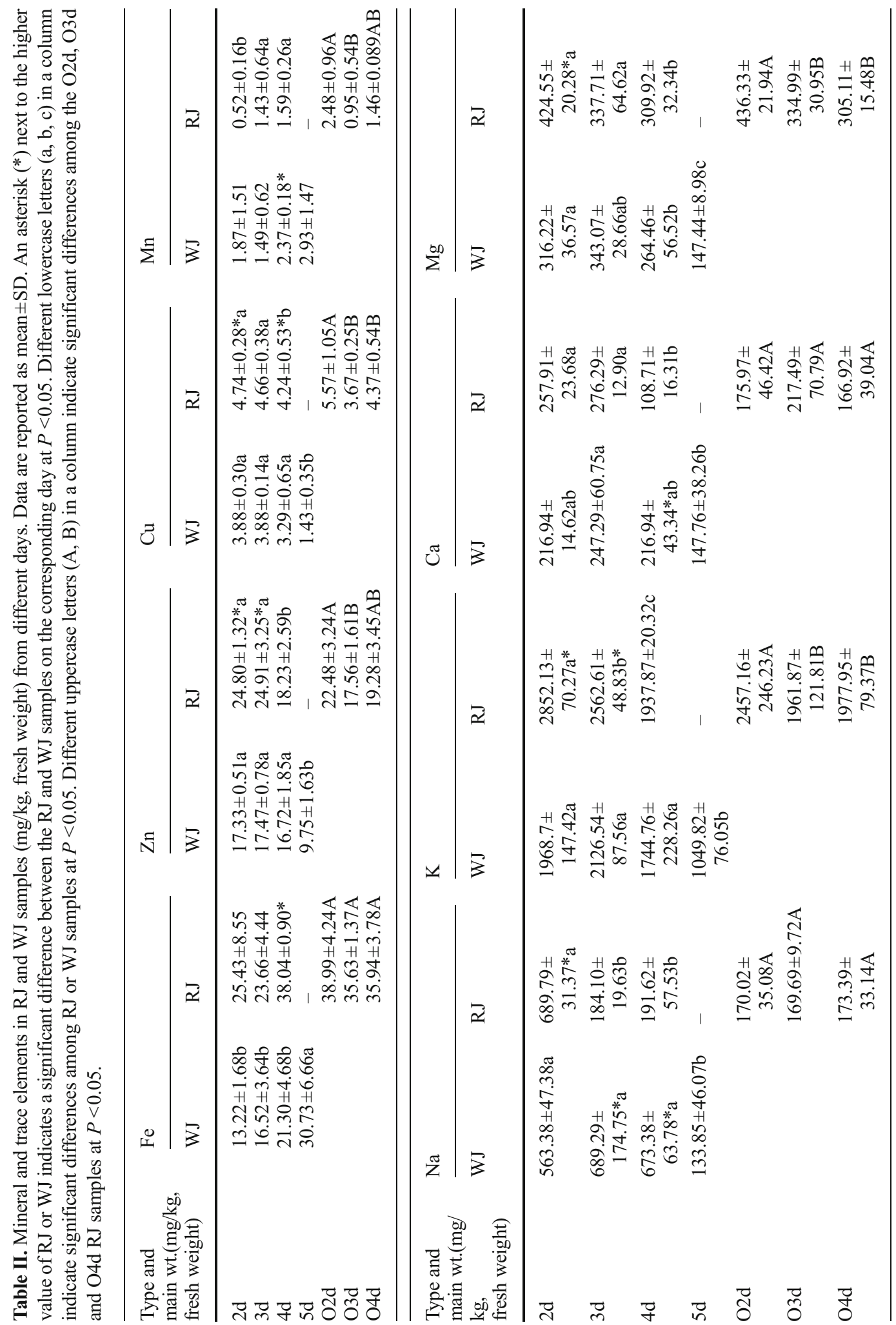


$P<0.01$ ). The content of $\mathrm{F}+\mathrm{G}$ in $\mathrm{RJ}$ was significantly higher than in WJ during the first three stages $(2 \mathrm{~d}: \mathrm{F}=103.4, P<0.01 ; 3 \mathrm{~d}: \mathrm{F}=182.5$, $P<0.01 ; \mathrm{d} 4: \mathrm{F}=66.4, P<0.01)$. The $\mathrm{F} / \mathrm{G}$ ratios of $\mathrm{WJ}$ and RJ were similar at $2 \mathrm{~d}$ and $3 \mathrm{~d}(2 \mathrm{~d}$ : $\mathrm{F}=4.37, P=0.082 ; 3 \mathrm{~d}: \mathrm{F}=1.55, P=0.26)$. The $\mathrm{F} / \mathrm{G}$ ratio of $3 \mathrm{~d}-\mathrm{WJ}$ was significantly higher than that of $3 \mathrm{~d}-\mathrm{RJ}$ ( $\mathrm{F}=52.86, P<0.01)$. The $\mathrm{F} / \mathrm{G}$ ratios for $4 \mathrm{~d}-$ and $5 \mathrm{~d}-\mathrm{WJ}$ were significantly higher than those for $2 \mathrm{~d}-$ and $3 \mathrm{~d}-\mathrm{WJ}(\mathrm{F}=6.04, P<0.05)$. No significant difference was found among $2 \mathrm{~d}-, 3 \mathrm{~d}-$ and $4 \mathrm{~d}-\mathrm{RJ}$ samples $(\mathrm{F}=0.43, P=0.66)$, but $\mathrm{O} 2 \mathrm{~d}$ and O3d RJ samples had significantly higher $F / G$ ratios than $\mathrm{O} 4 \mathrm{~d} \mathrm{RJ}(\mathrm{F}=7.03, P<0.05)$.

Mineral and trace element content in the WJ and RJ samples is shown in Table II. For the $2 \mathrm{~d}$ jellies, relatively high levels of zinc, copper, sodium, potassium and magnesium were found in RJ samples compared to WJ samples. On the third day, the RJ contained higher levels of zinc and potassium and lower levels of sodium than the WJ. On day 4, the content of iron and copper was higher in $\mathrm{RJ}$ than in $\mathrm{WJ}$, but the $\mathrm{WJ}$ contained significantly higher levels of manganese, sodium and calcium than the RJ. Most notably, zinc, copper, potassium and magnesium were found in the lowest concentrations in $5 \mathrm{~d}-\mathrm{WJ}$ samples, whereas the content of these minerals on $2 \mathrm{~d}, 3 \mathrm{~d}$ and $4 \mathrm{~d}-\mathrm{WJ}$ or $2 \mathrm{~d}$ and $3 \mathrm{~d}-\mathrm{RJ}$ samples was similar. The iron content of WJ was similar during the first 3 days and reached the highest levels at the $5 \mathrm{~d}$, but no significant difference was found for the RJ samples. With time, the manganese levels in RJ were lower on $2 \mathrm{~d}$ and increased significantly from the $3 \mathrm{~d}$, but no differences were found for WJ samples.

The O2d RJ contained significantly lower levels of moisture $(\mathrm{F}=13.14, P<0.01)$ and higher levels of protein, glucose, fructose, $\mathrm{Cu}, \mathrm{K}$ and $\mathrm{Mg}$ than the $\mathrm{O} 3 \mathrm{~d}$ and $\mathrm{O} 4 \mathrm{~d} \mathrm{RJ}$ samples (total protein: $\mathrm{F}=13.14, P<0.01$; glucose: $\mathrm{F}=8.44, P<0.01$; fructose: $\mathrm{F}=7.57, P<0.01 ; \mathrm{Cu}: \mathrm{F}=7.73$, $P<0.01 ; \mathrm{K}: \mathrm{F}=11.95, P<0.01 ;$ and $\mathrm{Mg}$ : $\mathrm{F}=39.32, P<0.01) . \mathrm{F}+\mathrm{G}$ of $\mathrm{O} 2 \mathrm{~d} \mathrm{RJ}$ was significantly higher than that of O3d RJ and O4d RJ samples $(\mathrm{F}=8.11, P<0.01)$. Significant differences were found in the content of 10-HDA, Fe, $\mathrm{Na}$ and $\mathrm{Ca}$ among these three RJ samples (10-HDA: $F=1.9$, $P>0.05 ; \mathrm{Fe}: \mathrm{F}=1.21, P>0.05 ; \mathrm{Na}: \mathrm{F}=0.02$, $P>0.05$; and $\mathrm{Ca}: \mathrm{F}=1.05, P>0.05)$. The lowest levels of $\mathrm{Zn}$ and $\mathrm{Mn}$ were found in the $\mathrm{O} 3 \mathrm{~d} \mathrm{RJ}$ samples ( $\mathrm{Zn}$ : $\mathrm{F}=3.32, P>0.05$; and $\mathrm{Ca}: \mathrm{F}=6.05$, $P<0.05)$.

\section{DISCUSSION}

It has long been believed that caste determination in honey bees is driven by the quantity and quality of brood food (Shuel and Dixon 1960). Although previous research has shown that RJ and WJ differ in some nutrients, this study showed a more significant difference in chemical composition between RJ and WJ. We found that RJ had lower moisture content than WJ. The WJ had high moisture content during the first 4 days, which decreased sharply on day 5 , while an increasing trend was found in the RJ. This is in agreement with previous studies (Elser 1929; Smith 1959; Dietz 1966). Elser (1929) found a decrease in the percentage of protein in queen larvae food, and a decreasing total protein content in RJ was also found in our study. In a study by von Planta (1888), higher protein and lower glucose content was found in the food of worker larvae less than 4 days old compared with older larvae. We also found significantly lower protein content in d5WJ and an increasing trend of glucose content in WJ. As Kamakura (2011) found that a single protein in royal jelly could induce queen differentiation, the royalactin content in RJ and WJ may also differ. Although numerous studies have confirmed the 10-HDA content of RJ (Takenaka and Echigo 1980; Lercker et al. 1992; Bloodworth et al. 1994; Koshio and de Almeida-Muradian 2003; Zheng et al. 2011), we have found no reports analyzing the 10-HDA content of WJ. This study provides compelling evidence that queen larvae are fed significantly higher amounts of 10-HDA than are worker larvae. The 10-HDA content in WJ was no more than $2 \%$ during the first 4 days, and this declined to the lowest level at $5 \mathrm{~d}$. Although the proportion of 10-HDA in RJ also showed a downward trend, the 10-HDA content remained at high levels. Previous studies found that the proportion of sugars in RJ for female larvae under 4 days old was approximately $34 \%$ (dry mass), whereas only $12 \%$ sugars were found in WJ fed to worker larvae 0-1.5 days old (Shuel and Dixon 1959). Similarly, Asencot and Lensky 
found that sugars in RJ for 1-3-day-old queen larvae were at levels approximately 4 times higher than those found in WJ (12.4 vs $3.1 \%$, dry mass) (Asencot and Lensky 1988). In our study, we found that the $\mathrm{G}+\mathrm{F}$ levels in RJ were approximately 4, 3 and 2 times higher than those in WJ at $\mathrm{d} 2, \mathrm{~d} 3$ and $\mathrm{d} 4$, respectively. These results are consistent with previous reports. Interestingly, the glucose and fructose content in the WJ maintained low levels at $\mathrm{d} 2, \mathrm{~d} 3$ and $\mathrm{d} 4$, and increased sharply at $\mathrm{d} 5$. This suggests that a higher proportion of honey is supplied to worker larvae at d5. Overall, RJ and WJ had similar Fe, Mn, $\mathrm{Ca}$ and $\mathrm{Mg}$ content in each age sample. The RJ contained higher levels of $\mathrm{Zn}, \mathrm{Cu}$ and $\mathrm{K}$ and a lower level of $\mathrm{Na}$ than that of $\mathrm{WJ}$. However, the Na levels in the 2d-RJ were higher, although they were significantly lower in the O2dRJ. Because the 2d-RJ consists of $1 \mathrm{~d}-\mathrm{RJ}$ and $\mathrm{O} 2 \mathrm{~d}-$ $\mathrm{RJ}$, the additional $\mathrm{Na}$ content worker bees feed female larvae the same food during their first 3 days of larval development (Haydak 1943, 1970; Nijhout and Wheeler 1982; Wilde and Beetsma 1982). Zheng et al. (2011) found that the composition of RJ harvested at different times varied significantly. Our results are in agreement, as RJ samples collected at $2 \mathrm{~d}, 3 \mathrm{~d}$ and $4 \mathrm{~d}$ varied significantly. Interestingly, when the mixture of RJ samples was separated into each corresponding day, we found that the composition of RJ samples fed to 3-day-old $(\mathrm{O} 3 \mathrm{~d})$ and 4-day-old $(\mathrm{O} 4 \mathrm{~d})$ queen larvae was nearly identical. This may provide insight into the basic biology of honey bees. The chemical composition of food fed to 2-, 3- and 4-day-old worker larvae was similar.

In mammals, gene expression and development can be influenced by nutrition (Dolinoy et al. 2007). Previous studies have shown that the rate of food intake is influenced by the level of sugars (Asencot and Lensky 1975, 1976; Lensky 1985), most likely associated with hormonally regulated mechanisms (Lensky et al. 1978; Asencot and Lensky 1984). Although Kamakura's work (2011) is based on the effects of a single protein on queen differentiation, it is unquestionably a good start in understanding the relationship between nutrition and caste determination. In this study, tremendous variations in chemical composition were observed between RJ and WJ samples. We still know very little about the role of these nutrients in honey bee caste determination. Therefore, much still remains to be explored of the relationship between nutritional effects and polyphenism in honey bees.

\section{ACKNOWLEDGMENTS}

This work was financially supported by Shandong Province Agricultural Fine Varieties Breeding Projects (2014-2016), the earmarked fund for the China Agriculture Research System (No. CARS-45), and the National Natural Science Foundation of China (No. 31172275).

Comparaison de la composition en nutriments de la gelée royale et de la gelée pour ouvrières chez les abeilles (Apis mellifera)

substance chimique / valeur nutritionnelle / protéines / fructose / glucose

Vergleich der Nährstoffzusammensetzung von Königinnen- und Arbeiterinnenfuttersaft der Honigbiene (Apis mellifera )

chemische Zusammensetzung / Gelée royale / Arbeiterinnenfuttersaft / Nahrungseffekt

\section{REFERENCES}

Asencot, M., Lensky, Y. (1975) Supplemented worker jelly causing differentiation of female honey bee larvae to queens. Symp. Pheromones and Defensive Secretions in Social Insects, IUSSI, Dijon.

Asencot, M., Lensky, Y. (1976) The effect of sugars and juvenile hormone on the differentiation of the female honeybee larvae (Apis mellifera L.) to queens. Life Sci. 18(7), 693-699

Asencot, M., Lensky, Y. (1984) Juvenile hormone induction of 'queenliness' on female honey bee (Apis mellifera L.) larvae reared on worker jelly and on stored royal jelly. Comp. Biochem. Physiol. Part B: Biochem. 78(1), 109-117

Asencot, M., Lensky, Y. (1985) The phagostimulatory effect of sugars on the induction of "queenliness" in female honeybee (Apis mellifera L.) larvae. Comp. Biochem. Physiol. Part A: Physiol. 81 (1), 203-208

Asencot, M., Lensky, Y. (1988) The effect of soluble sugars in stored royal jelly on the differentiation of female honeybee (Apis mellifera L.) larvae to queens. Insect Biochem. 18(2), 127-133 
Benfenati, L., Sabatini, A., Nanetti, A. (1986) Composizione in sali minerali della gelatina reale. Apicoltura 2, 129-143

Bloodworth, B.C., Harn, C.S., Hock, C.T., Boon, Y.O. (1994) Liquid chromatographic determination of trans-10-hydroxy-2-decenoic acid content of commercial products containing royal jelly. J. AOAC Int. 78(4), 1019-1023

Boselli, E., Caboni, M.F., Sabatini, A.G., Marcazzan, G.L., Lercker, G. (2003) Determination and changes of free amino acids in royal jelly during storage. Apidologie 34 (2), 129-138

Chen, Y.Z., Zhang, L.Q., Song, X.H., Wang, Y.X. (2006) Comparison of egg quality of 7 Shandong indigenous laying hens. Studies of Trace Elements and Health $23(6), 32-34$

Chen, S.L., Su, S.K., Lin, X.Z. (2002) An introduction to high-yielding royal jelly production methods in China. Bee World 83, 69-77

Dietz, A. (1966) Influence of environmental and nutritional factors on growth and caste determination of female honey bees.Ph.D. Thesis, University of Minnesota, St. Paul, MN.

Dolinoy, D.C., Das, R., Weidman, J.R., Jirtle, R.L. (2007) Metastable epialleles, imprinting, and the fetal origins of adult diseases. Pediatr. Res. 61, 30-37

Elser, E. (1928) Die chemische zusammensetzung einiger blütenstaubarten mit besonderer berücksichtigung der für die biene wertvollen nährstoffe.

Elser, E. (1929). Die chemische zusammensetzung der nahrungsstolfe der biene. Märkische Bienenztg. 19: 211-5, 232-5, 248-52.

Garcia-Amoedo, L.H., Almeida-Muradian, L.B. (2007) Physicochemical composition of pure and adulterated royal jelly. Quím. Nova 30 (2), 257-259

General Administation of Quality Supervision, Inspection and Quarantine of the People's Republic of China (2008) The quality standard of royal jelly.

Haydak, M.H. (1943) Larval food and development of castes in the honeybee. J. Econ. Entomol. 36(5), 778-792

Haydak, M.H. (1970) Honey bee nutrition. Annu. Rev. Entomol. 15(1), 143-156

Hoegger, R. (1998) Training papers nitrogen determination according to Kjeldahl. Büchi Labortechnik AG. Flawil 1,18

Kamakura, M. (2011) Royalactin induces queen differentiation in honeybees. Nature 473 (7348), 478-483

Koshio, S., de Almeida-Muradian, L.B. (2003) Aplicação da CLAE para determinação do ácido 10-hidróxi-2decenóico (10-HDA) em geléia real pura e adicionada a mel brasileiro. Quím. Nova 26(5), 670-673

Lensky, Y. (1985) The phagostimulatory effect of sugars on the induction of "queenliness" in female honeybee (Apis mellifera L.) larvae. Comp. Biochem. Physiol. Part A: Physiol. 81 (1), 203208
Lensky, Y., Baehr, J., Porcheron, P. (1978) Dosages radioimmunologiques des ecdysones et des hormones juvéniles au cours du développement post-embryonnaire chez les ouvrières et les reines d'abeille (Apis mellifica L. var. ligustica). C.R. hebd. Séances Acad. Sci., Série D - Sciences nat 287 (8), 821-824

Lercker, G., Caboni, M., Vecchi, M., Sabatini, A., Nanetti, A. (1992) Caratterizzazione dei principali costituenti della gelatina reale. Apicoltura 8, 27-37

Lercker, G., Capella, P., Conte, L., Ruini, F., Giordani, G. (1981) Components of royal jelly: I. Identification of the organic acids. Lipids 16(12), 912-919

Messia, M.C., Caboni, M.F., Marconi, E. (2005) Storage stability assesment of freeze dried RJ by furosine determination. J. Agric. Food Chem. 53(11), 4440-4443

Nijhout, H.F., Wheeler, D.E. (1982) Juvenile hormone and the physiological basis of insect polymorphisms. Quart. Rev. Biol.: 109-133.

Noda, N., Umebayashi, K., Nakatani, T., Miyahara, K., Ishiyama, K. (2005) Isolation and characterization of some hydroxy fatty and phosphoric acid esters of 10hydroxy-2-decenoic acid from the royal jelly of honeybees (Apis mellifera). Lipids 40 (8), 833-838

Pamplona, L.C., Azedo, R.A., Oliveira, K.C.L., GarciaAmoedo, L.H., Almeida-Muradian, L.B. (2004) Physicochemical analyses indicated to the quality control of royal jelly with honey. Food Sci. Technol. (Campinas) 24 (4), 608-612

Ramadan, M.F., Al-Ghamdi, A. (2012) Bioactive compounds and health-promoting properties of royal jelly: A review. J. Funct. Foods 4 (1), 39-52

Sabatini, A.G., Marcazzan, G.L., Caboni, M.F., Bogdanov, S., Almeida-Muradian, L. (2009) Quality and standardisation of royal jelly. J. ApiProduct ApiMedical Sci. 1 (1), 1-6

Sesta, G. (2006) Determination of sugars in royal jelly by HPLC. Apidologie 37 (1), 84-90

Shuel, R., Dixon, S. (1959) Studies in the mode of action of royal jelly in honeybee development: ii. respiration of newly emerged larvae on various substrates. Can. J. Zool. 37 (5), 803-813

Shuel, R., Dixon, S. (1960) The early establishment of dimorphism in the female honeybee, Apis mellifera L. Insectes Soc. 7 (3), 265-282

Simúth, J. (2001) Some properties of the main protein of honeybee (Apis mellifera) royal jelly. Apidologie 32 (1), 69-80

Smith, M.V. (1959) Queen differentiation and the biological testing of royal jelly. Mem. Cornell Agric. Exp. Sta. No. 356.

Stocker, A., Schramel, P., Kettrup, A., Bengsch, E. (2005) Trace and mineral elements in royal jelly and homeostatic effects. J. Trace Elem. in Medicine and Biol. 19 (2), 183-189

Takenaka, T., Echigo, T. (1980) Chemical composition of royal jelly. Bull. Fac. Agric Tamagawa Univ 20, 7178 
von Planta, A. (1888) Ueber den Futtersaft der Bienen. Z. Physiol. Chern. 12, 327-354

Wilde, J., Beetsma, J. (1982) The physiology of caste development in social insects. Adv. Insect Physiol. 16, $167-246$
Winston, M.L. (1991) The biology of the honey bee. Harvard University Press.

Zheng, H.Q., Hu, F.L., Dietemann, V. (2011) Changes in composition of royal jelly harvested at different times: consequences for quality standards. Apidologie 42, 39-47 